\title{
Mutational analysis of the dimethylsulfoxide respiratory (dor) operon of Rhodobacter capsulatus
}

\author{
Anthony L. Shaw, ${ }^{1}$ Silke Leimkuhler, ${ }^{3}$ Werner Klipp, ${ }^{3}$ \\ Graeme R. Hanson ${ }^{2}$ and Alastair G. McEwan ${ }^{1}$
}

Author for correspondence: Alastair G. McEwan. Tel: +61733654878 . Fax: +61733654620.
e-mail : mcewan (a biosci.uq.edu.au

1,2 Department of

Microbiology ${ }^{1}$ and Centre

for Magnetic Resonance?

The University of

Queensland, Brisbane

4072, Australia

3 Lehrstuhl für Biologie der Mikrooganismen, Ruhr

Universitat Bochum,

D-44780, Bochum, Germany

\begin{abstract}
Four genes, dorC, dorD, dorB and dorR of the DMSO respiratory gene cluster of Rhodobacter capsulatus have been identified and sequenced. dor $C$ encodes a pentahaem c-type cytochrome of the NirT class and the derived DorC protein sequence shows highest similarity to TorC from the Escherichia coli trimethylamine- $\mathrm{N}$-oxide (TMAO) respiratory system. Mutagenesis of dorC resulted in the loss of a $46 \mathrm{kDa}$ haem-staining polypeptide from membranes of $R$. capsulatus. dorD encodes a protein with highest sequence similarity to TorD from the $E$. coli TMAO respiratory system. DMSO reductase polypeptide (DorA) could not be detected in cell-free extracts of a dorD mutant and it is suggested that DorD has a role in stabilizing the DorA apo-protein prior to insertion of the pterin molybdenum cofactor. dorB encodes a protein with highest sequence similarity to NapD of Paracoccus denitrificans. Mutagenesis of dorB reduced the activity of DMSO reductase and led to the accumulation of a larger form of the enzyme that is presumed to represent a cytoplasmic precursor polypeptide. It is suggested that DorB has a role in the biogenesis of DMSO reductase prior to its secretion into the periplasm. dorR is transcribed in the opposite direction to dorC. The derived amino acid sequence of DorR indicates that it is a response regulator and mutation of dorR shows that it is essential for expression of the dorCDA operon. Expression of a chromosomal dorA:: lacZ fusion was also dependent on the transcriptional regulator Fnr. The intergenic region between dorR and dorC contains four putative binding sites for DorR but no binding site for Fnr was identified.
\end{abstract}

Keywords: dimethylsulfoxide respiration, Rhodobacter capsulatus

\section{INTRODUCTION}

The ability to use DMSO and trimethylamine- $N$-oxide (TMAO) as electron acceptors is widespread among purple non-sulfur phototrophic bacteria (Zannoni, 1995). In Rhodobacter capsulatus DMSO reductase is located in the periplasm and electron transfer to this terminal reductase has been shown to involve cytochromes (McEwan et al., 1989). Analysis of transposon mutants has shown that a single oxidoreductase is responsible for the reduction of both TMAO and DMSO

Abbreviations: Moco, pterin molybdenum cofactor; TMAO, trimethylamine- $\mathrm{N}$-oxide; $\mathrm{Gm}$, gentamicin; Tc, tetracycline.

The GenBank accession number for the sequence reported in this paper is U49506.
(Kelly et al., 1988). Since the apparent second order rate constant $\left(k_{\text {cat }} / K_{\mathrm{m}}\right)$ of the enzyme is greater towards DMSO than TMAO (Satoh \& Kurihara, 1987) the enzyme is described as a DMSO reductase. The genes encoding DMSO reductase from R. capsulatus (Shaw et al., 1996; Knaeblein et al., 1996) and Rhodobacter sphaeroides (Yamamoto et al., 1995) have been sequenced. Sequence analysis reveals that the $R$. capsulatus DMSO reductase (Dor A) is more closely related to the TMAO reductase (TorA) of Escherichia coli $(48 \%$ identical) than to DMSO reductase (DmsA) of E. coli ( $26 \%$ identity). For this reason we refer to genes encoding DMSO respiratory components in Rhodobacter as dor genes (Shaw et al., 1996).

DMSO/TMAO reductases are members of the molybdenum oxotransferase family of enzymes (Kisker et 
al., 1997). These enzymes catalyse the transfer of an oxygen atom to or from a substrate in a reaction which is linked to a two-electron transfer process. The unifying feature of these enzymes is the presence of a pterin molybdenum cofactor (Moco) at the active site. Oxomolybdenum enzyme research has rapidly expanded with the publication of the crystal structures of Mococontaining enzymes, including DMSO reductase from R. sphaeroides (Schindelin et al., 1996) and R. capsulatus (Schneider et al., 1996; McAlpine et al., 1997). The simplicity of DMSO reductase has made it an excellent system for spectroscopic investigations of oxomolybdenum enzymes (Bennett et al., 1994) and recent advances have opened the way for studies of structurefunction relationships within the enzyme. As part of our efforts to understand the structure and mechanism of DMSO reductase from $R$. capsulatus we have cloned and sequenced the genes which flank $\operatorname{dor} A$. It was expected that this would identify proteins involved in electron transport to DMSO reductase or proteins involved in the expression of DMSO reductase. In this paper we report the mutagenesis of three genes of the dor operon and the phenotypic characterization of the resulting mutants.

Recently, the sequence of the dor gene cluster of $R$. sphaeroides has been reported and mutational analysis of dor genes carried out (Mouncey et al., 1997; Mouncey \& Kaplan, 1998). This work identified a two-component sensor kinase/response regulator, DorS and DorR, that is required for the DMSO-dependent induction of the dor operon (Mouncey \& Kaplan, 1998). In this paper we also describe aspects of the regulation of dor operon expression in $R$. capsulatus.

\section{METHODS}

Bacterial strains and plasmids. Bacterial strains and plasmids used in this work are listed in Table 1.

DNA sequencing and library screening. Plasmid pALS2 (Shaw et al., 1996), which contains the complete dorA sequence, also contains the complete dor $D$ sequence and a $C$-terminal portion of $\operatorname{dor} \mathrm{C}$. The partial sequence data from $\operatorname{dor} \mathrm{C}$ were used to design a 30 bp oligonucleotide $\left(5^{\prime}\right.$-TGCGGCACCTGCCACGTGCTGCCCCATACC-3') which corresponds to a conserved haem- $c$ binding site $(\mathrm{C}-\mathrm{X}-\mathrm{X}-\mathrm{C}-\mathrm{H})$. This probe was labelled at the $3^{\prime}$ end with fluorescein-11-dUTP using an Amersham $3^{\prime}$ oligonucleotide labelling kit according to the manufacturer's instructions. The labelled probe was used to screen a R. capsulatus $\lambda$-ZAPII expression library (Stratagene), prepared as described by Shaw et al. (1996), using Amersham ECL detection reagents and Hybond- $\mathrm{N}+$ membranes as described by the manufacturer, except that the membranes were blocked in $5 \%(\mathrm{w} / \mathrm{v})$ non-fat milk powder in Trisbuffered saline (20 mM Tris/ $\mathrm{HCl}, \mathrm{pH} 7 \cdot 5,150 \mathrm{mM} \mathrm{NaCl})$. This screening identified several clones that hybridized with the $\operatorname{dor} C$ probe. These clones were purified and the phage excised to form phagemids harboured in E. coli XL-1 Blue MRF' (Stratagene) according to protocols supplied by Stratagene.

Phagemids pALS3 and pALS4 were selected and initial sequencing was performed using primers designed from sequence data derived from pALS2 and the T3 sequencing primer. Additional primers were made as more sequence was determined. Phagemid DNA was prepared using Qiagen columns according to the manufacturer's instructions. Automated dye terminator sequencing was performed with a Perkin Elmer sequencing premix as described previously (Shaw et al., 1996). The reaction products were analysed on an Applied Biosystems 373A automated sequencer. All sequencing was performed on both strands and sequencing reactions were performed in triplicate. All sequence alignments, manipulations and analyses were performed using programs in the Wisconsin GCG software package version 8.1-UNIX.

Construction of dorA, dorC, dorD, dorB and dorR mutants. All DNA cloning was performed according to standard methods (Sambrook et al., 1989) using E. coli JM109 (YanischPerron et al., 1985) for routine cloning. A dorA mutant was constructed using a 3451 bp PstI-BamHI fragment of pALS2 (Shaw et al., 1996) containing the complete dor A gene which was cloned into Pst / BamHI-digested pSVB25 (Pharmacia). A $6.5 \mathrm{~kb}$ BglII-HindIII fragment from pWKR459II containing $m o b$ and tetracycline $(\mathrm{Tc})$ resistance regions (Simon et al., 1983) was cloned into this plasmid digested with Bam HI and $H$ indIII. The resulting construct was cut with EcoRI, removing a $1515 \mathrm{bp}$ internal fragment of $\operatorname{dor} A$. A $2.6 \mathrm{~kb}$ Gentamicin $(\mathrm{Gm})$ resistance interposon was cloned from EcoRI-digested R440 (Hirsch \& Beringer, 1984) into the EcoRI-digested dorA gene in pSVB25. The orientation of the $\mathrm{Gm}$ resistance interposon was determined and two plasmids, pALS41 and pALS42, were selected for further cloning, each containing the $\mathrm{Gm}$ resistance interposon in opposite orientations. pALS41 contains a $\mathrm{Gm}$ resistance interposon that is transcribed in the same direction as $\operatorname{dor} A$. For mutagenesis of $\operatorname{dor} A$, pALS41 was mobilized from E. coli S17-1 into R. capsulatus by conjugation. Colonies where a double cross-over had occurred were identified as exhibiting resistance to $\mathrm{Gm}$ and sensitivity to $\mathrm{Tc}$. In this way the wild-type chromosomal copy of $\operatorname{dor} A$ was exchanged for a dor A deletion-insertion mutation. For mutagenesis of $\operatorname{dor} \mathrm{C}$ a $2 \cdot 8 \mathrm{~kb}$ EcoR I fragment was cloned from pALS3 into EcoRI-digested pK18 (Pridmore, 1987). A $2.6 \mathrm{~kb}$ $\mathrm{Gm}$ resistance interposon (Hirsch \& Beringer, 1984) was cloned into the ClaI site in $\operatorname{dor} C$ and constructs were screened to determine the orientation of the $\mathrm{Gm}$ resistance cassette. Two constructs, each containing $\mathrm{Gm}$ resistance interposons in opposite orientations and thus opposite directions of transcription with respect to $\operatorname{dor} C$ were chosen. A $5.4 \mathrm{~kb}$ EcoRI fragment, containing $\operatorname{dor} \mathrm{C}$ with the $\mathrm{Gm}$ resistance cassette inserted, was cloned from pK18 into EcoRI-digested pSUP202 (Labes et al., 1990). The resulting constructs, pALS71 and pALS72, each containing the Gm resistance cassette in opposite orientations, were transformed into E. coli S17-1.

The dorD mutation was made by first cloning a $2 \cdot 2 \mathrm{~kb} B a m \mathrm{HI}-$ Sall fragment from pALS2 into BamHI/Sall-digested pBluescript KS(+) (Stratagene). This construct was digested with PstI which cuts $\operatorname{dorD}$. The $5^{\prime}$ overhangs generated by Pst I digestion were filled with T4 DNA polymerase (New England Biolabs). A Gm resistance interposon (Hirsch \& Beringer, 1984) was cut with EcoRI and the 3' overhangs removed with T4 DNA polymerase (New England Biolabs) to form blunt ends. The two fragments were ligated to give plasmids that contained a $\mathrm{Gm}$ resistance interposon inserted into dorD. Again, these plasmids were screened to obtain two constructs, each with opposite orientations of the Gm resistance interposon with respect to dorD. These two plasmids were linearized with BamHI and cloned into BamHI-digested 
Table 1. Bacterial strains and plasmids used in this study

\begin{tabular}{|c|c|c|}
\hline Strain/plasmid & Genotype and properties* & Reference or source \\
\hline \multicolumn{3}{|l|}{ R. capsulatus } \\
\hline $37 \mathrm{~b} 4$ & Wild-type & Kaufmann et al. (1984) \\
\hline DOR-R1 & dorR::Gm & This work \\
\hline RGK295 & $\Delta f n r:: \Omega K n$ & Zeilstra-Ryalls et al. (1997) \\
\hline \multicolumn{3}{|l|}{ E. coli } \\
\hline XL-1 Blue MRF' & Host strain for $\mathrm{pBK}$ phagemid vectors & Stratagene \\
\hline$S 17-1$ & RP4-2 (Tc:: Mu) (Km:: $\mathrm{Tn} 7)$; integrated into chromosome & Simon et al. (1983) \\
\hline \multicolumn{3}{|c|}{ 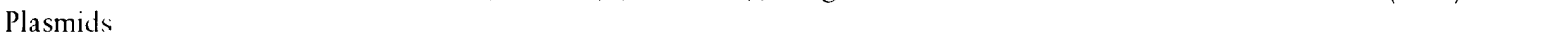 } \\
\hline pALS3 & $\begin{array}{l}\text { pBK-CMV phagemid vector containing } 4.8 \mathrm{~kb} R \text {. capsulatus } \\
\text { genomic DNA; } \mathrm{Km}^{\mathrm{r}}\end{array}$ & This study \\
\hline pALS4 & $\begin{array}{l}\text { pBK-CMV phagemid vector containing } 5 \cdot 1 \mathrm{~kb} R \text {. capsulatus } \\
\text { genomic DNA; } \mathrm{Km}^{r}\end{array}$ & This study \\
\hline pUCs & $\mathrm{Ap}^{\mathrm{r}} l a c Z \alpha$ & Vieira \& Messing (1982) \\
\hline pWKR459II & $\mathrm{pK} 18:: m o b(\mathrm{RP} 4), \mathrm{Tc}^{\mathrm{r}}$ & W. Klipp \\
\hline pALS48 & Mobilizable plasmid carrying dorR:: Gm & This study \\
\hline pJK1 & $\begin{array}{l}5 \mathrm{~kb} \text { Bam HI DNA fragment containing the } R . \text { capsulatus } \\
\text { dorA gene in pBluescript } \mathrm{SK}(-)\end{array}$ & Knaeblein et al. (1996) \\
\hline $\mathrm{pML} ; \mathrm{B}+)$ & $\begin{array}{l}\text { Mobilizable, promoterless } l a c Z Y A \text { transcriptional fusion } \\
\text { vector, } T c^{r}\end{array}$ & Labes et al. (1990) \\
\hline pSL111 & $\begin{array}{l}\text { Mobilizable plasmid carrying a dor } A: \text { : lacZYA } \\
\text { transcriptional fusion }\end{array}$ & This study \\
\hline
\end{tabular}

*Ap, ampicillin; Km, kanamycin.

pSUP202-Spec (Labes et al., 1990). These plasmids, pALS81 and pALS82, were then transformed into E. coli S17-1.

A mutation in $\operatorname{dor} B$ was generated by cloning a $1.8 \mathrm{~kb}$ Pst I$E c o$ RI DNA fragment from pALS2 into the PstI and EcoRI sites of pSVB30 (Pharmacia). This construct was then digested with Ball that cuts only dorB. A Gm resistance interposon with blunt ends was ligated into the BalI site and constructs were screened to identify plasmids with the $\mathrm{Gm}$ resistance interposon inserted in both orientations. The two plasmids were then cut with PstI and an $8.4 \mathrm{~kb} P s t \mathrm{I}$ DNA fragment from pWKR459II, containing $m o b$ and Tc resistance genes, was cloned into this site generating plasmids pALS91 and pALS92.

For construction of a dorR mutant, a 1294 bp Pst I-EcoRI fragment from pALS4 was cloned into pUC8, a 942 bp Eco0109I fragment containing part of $\operatorname{dor} \mathrm{C}$ and pUC8 was removed and the plasmid recircularized. This created a plasmid in which dorR contained the only SalI site and this enabled a $2.6 \mathrm{~kb} \mathrm{Gm}$ resistance interposon to be inserted into dorR. Constructs were screened to identify a plasmid in which the $\mathrm{Gm}$ interposon had been inserted in a direction that was opposite to the direction of transcription of dorR. The resulting plasmid was digested with EcoRI and an $8.8 \mathrm{~kb}$ EcoRI fragment from plasmid pWKR459II containing the $\mathrm{RP} 4: m o b$ locus and the Tc resistance gene was cloned into this site creating plasmid pALS48. After transformation into

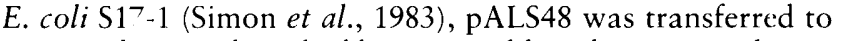
R. capsulatus as described by Masepohl et al. (1988). Colonies where a double cross-over had occurred were identified as exhibiting resistance to $\mathrm{Gm}$ and sensitivity to Tc.

Bacterial matings with $R$. capsulatus $37 \mathrm{~b} 4$ were performed according to the filter mating method as described by
Masepohl et al. (1988). Mutants were selected by growing the cells on RCV medium (Weaver et al., 1975) supplemented with $\mathrm{Gm}$ at $4 \mu \mathrm{g} \mathrm{m}^{-1}$. Double cross-over events were then selected for by isolating cells that were Gm-resistant but sensitive to spectinomycin at a concentration of $25 \mathrm{\mu g} \mathrm{m}^{-1}$ (dorD mutants) or $\mathrm{Tc}$ at $1 \mu \mathrm{g} \mathrm{ml}^{-1}$ (dorC mutants and $\operatorname{dor} B$ mutants) in RCV medium. E. coli was selected against by the inclusion of tellurite at $20 \mu \mathrm{g} \mathrm{ml}^{-1}$. The dorC mutants are designated mutant $\mathrm{C} 1$, in which the $\mathrm{Gm}$ resistance gene is transcribed in the opposite direction to $\operatorname{dor} C$, and mutant $\mathrm{C} 2$, in which the $\mathrm{Gm}$ resistance gene is transcribed in the same direction as dor C. The dorD mutants are designated mutant D1, in which the $\mathrm{Gm}$ resistance gene is transcribed in the opposite direction to dorD, and mutant D2, in which the Gm resistance gene is transcribed in the same direction as $\operatorname{dor} D$. The $\operatorname{dor} B$ mutants are designated mutant $\mathrm{B} 1$, in which the $\mathrm{Gm}$ resistance gene is transcribed in the opposite direction to $\operatorname{dor} B$, and mutant B2, in which the $\mathrm{Gm}$ resistance gene is transcribed in the same direction as $\operatorname{dor} B$.

Construction of chromosomal dorA:: lacz fusions. A BamHIHindIII fragment containing dorA from plasmid pJK1 (Knaeblein et al., 1996) was cloned into pSUP401 (Simon et al., 1983) generating pSL109. The lacZYA genes from pML5(B+) (Labes et al., 1990) were cloned into the BamHI site of pSL109 to produce $\mathrm{pSL111}$. This plasmid was transferred from E. coli S17-1 to $R$. capsulatus as described above and exconjugants with a $\operatorname{dor} A$ : : lac $Z$ fusion integrated into the chromosome via a single cross-over were identified by selection for $T_{c}$ resistance.

Cell growth and $\boldsymbol{\beta}$-galactosidase assays. $R$. capsulatus was grown chemoheterotrophically on RCV medium with oxygen as electron acceptor. The cells were shaken vigorously (250 
r.p.m.) in a total volume that was less than $10 \%$ of the flask volume. For measurement of $\phi[\operatorname{dor} A:$ : lac $Z]$ expression under aerobic conditions a $2 \%$ inoculum of cells was transferred to $20 \mathrm{ml} \mathrm{RCV}$ medium in a $250 \mathrm{ml}$ flask and the cells were shaken for a further $7 \mathrm{~h}$ before harvesting. For measurements of anaerobic induction of $d o r$ expression, aerobically grown cells were inoculated $(7.5 \%$ inoculum) into $220 \mathrm{ml} \mathrm{RCV}$ medium in a $250 \mathrm{ml}$ flask. The cells were incubated for $15 \mathrm{~h}$ in the dark without shaking. DMSO or TMAO were added to a final concentration of $30 \mathrm{mM} . \beta$-Galactosidase assays were performed using the method of Miller (1972). All experiments were performed in triplicate and the results presented represent the mean of three independent experiments.

Western blots, haem stain and enzyme assay. Cells from cultures grown photoheterotrophically for $24 \mathrm{~h}$ were harvested by centrifugation at $10000 \mathrm{~g}$ in a Beckman JA20 rotor for $20 \mathrm{~min}$ and resuspended in $50 \mathrm{mM}$ Tris/ $\mathrm{HCl}, \mathrm{pH} \mathrm{8.0.}$ Crude cell extracts were prepared by passage of the cells twice through a French Pressure cell at 11000 p.s.i. Insoluble matter was removed by centrifugation at $10000 \mathrm{~g}$ in a Beckman JA20 rotor for $20 \mathrm{~min}$. The resulting supernatant was used as a crude extract. Protein concentration was determined by the bicinchoninic acid method (Sigma) using bovine serum albumin as standard. DMSO reductase activity was determined as described previously (McEwan et al., 1985). Western blotting of cell extracts and development of blots using anti-DMSO reductase antibody was performed as described by Hatton $e t$ al. (1994). Staining of proteins separated by SDS-PAGE for haem-dependent peroxidase activity was performed as described by Vargas et al. (1993). ECL reagents and 'rainbow' molecular mass markers were obtained from Amersham.

\section{RESULTS}

\section{Nucleotide sequence and organization of the dor operon}

The cloning of $\operatorname{dor} A$ from two distinct libraries of $R$. capsulatus strain 37b4 DNA has already been reported, the nucleotide sequences have been deposited in the GenBank database (U49506 and X95407) and the primary structure of DMSO reductase has been analysed (Shaw et al., 1996; Knaeblein et al., 1996). Analysis of the nucleotide sequence $5^{\prime}$ to $\operatorname{dor} A$ identified two ORFs that we have named $\operatorname{dorD}$ and $\operatorname{dor} C$, for reasons explained below (Fig. 1). The translation termination codon of dorD overlaps with the translation initiation codon of $\operatorname{dor} A$ and the start codon for translation of dorD also overlaps the stop codon of $\operatorname{dor} C$ (Fig. 1). Another ORF, which encodes a response regulator in a two-component signal transduction system (designated dorR), was identified approximately 180 bp upstream of the dorC start codon (Fig. 1). dorR is transcribed in the opposite direction to $\operatorname{dor} C D A$ (Fig. 1). The $180 \mathrm{bp}$ region which lies between $\operatorname{dor} R$ and $\operatorname{dor} C$ represents a potential region for regulation of the expression of the dor operon. Inspection of the nucleotide sequence of this region is consistent with this view since this DNA contains four Tor boxes (data not shown) which have been shown to bind the response regulator TorR in the tor operon of E. coli (Simon et al., 1995). Analysis of DNA 3 ' to $\operatorname{dor} A$ identified a stable double stem-loop structure which may act as a transcription terminator (Fig. 1). Another ORF was identified downstream of this putative terminator which we have designated $\operatorname{dor} B$ (Fig. 1). dor $B$ is located between $\operatorname{dor} A$ and a gene cluster encoding enzymes involved in Moco biosynthesis (Solomon et al., 1999).

\section{Analysis of DorC, DorD, DorB and DorR}

The putative DorC apoprotein has a molecular mass of $39690 \mathrm{Da}$ and a calculated pI of 10.52. The protein also contains five motifs for the binding of $c$-type haems (Fig. 2). A possible signal peptidase cleavage site was identified between amino acids 24 and 25 using the method of Von Heijne (1986) which suggests that the protein might be synthesized as a pre-protein. Hydropathy plots did not indicate that DorC possessed any hydrophobic regions of sufficient size to be membrane-spanning helices. DorC has a hydrophobic $\mathrm{N}$-terminal sequence that could act as a membrane anchor. Amino acid sequence comparisons revealed that DorC has highest sequence similarity to TorC $(33.5 \%$ identity, $48.5 \%$ similarity). TorC has been shown to be a member of the NirT family of multi-haem $c$-type cytochromes, most of which possess four haem $c$ prosthetic groups (Berks et al., 1995a). The sequence alignment (Fig. 2) shows that four of the $c$-type-haem-binding motifs of DorC and

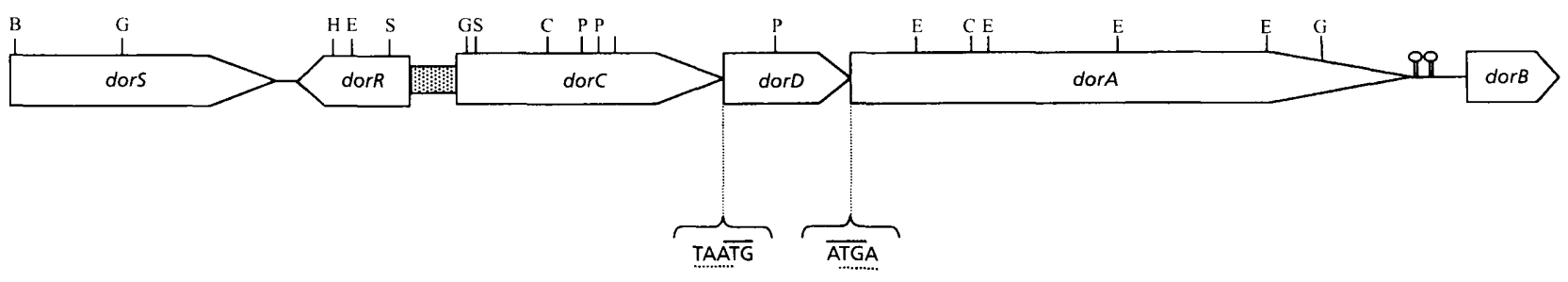

Fig. 1. Organization of the dor operon of R. capsulatus. B, BamHI; C, Clal; E, EcoRI; P, Pstl; S, Smal. The shaded region represents the putative $d o r$ regulatory sequences. Overlapping start and stop codons are indicated as a solid overline and a dashed underline, respectively. 




R. Caps DorC $(41-100)$

R. sphr DorC $(61-120)$

E. Coli TorC $(48-106)$

P. stut NirT $(58-116)$

R. sphr NapC $(54-112)$

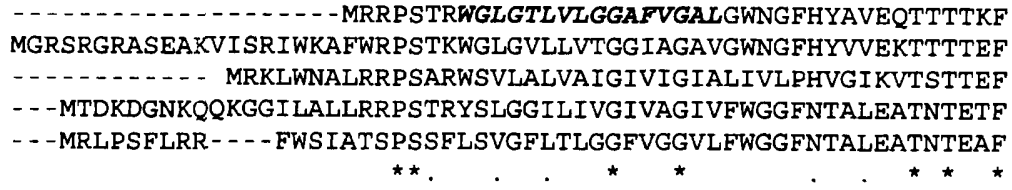

CLSCHSMQGQLRRIQDQPSNYVNPMGVRAECADCHVPKSGWRAFTGPSAGRRRSVGEITG CISCHSMRDNNYEEYKTTIHYQNTSGVRAECADCHVPKSGWKLYRAKLLAAKDLWGEIQG CVSCHSMQP - VYEEYKQSVHFQNASGVRAE CHDCHI P PDI PGMVKRKLEASNDIYQTFIA CISCHEMGDNVY PEYKET IHYANRTGVRAT CPDCHVPRDWTHKMVRKVEASKELWGKIVG CTSCHEMQSNVFEELTRTVHYTNRSGVSAG CPDCHVPHEWTDKIARKMQASKEVWGTLFG

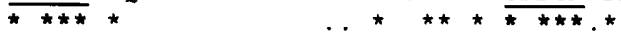

R. Caps DOrC (101-159) -KVDTPDKIRGAPARNGRNRLGRHEGEDSVGCRSCHSNTMSMDLRPSNQPDAAMQMHQAM

$R$. sphr DOrC (121-177) -TIDTREKFEAHRLEMAETVWADMKANDSATCRTCHSFNAMDFAHQKPEASKQM-QQAM

E. Coli TorC (107-177) HSIDTPEKFEAKRAELAEREWARMKENNSAT CRSCHNYDAMDHAKQHPEAARQM--KVAA

$P$. stut NirT (117-173) -TIDTAEKFEAKRLTLARREWARMRASDSRECRNCHSLESMSSDMQKQRARKQH--EMAR $R$. sphr NapC $(113-171)$-TIDTRRKFLDNRLRLAEHEWARLKANDSLE $\frac{\text { CRNCHSEVAMDFTRQTDRAAQIHTQYLIQ }}{\star \star \star \star}$

R. caps DorC (160-219) KDGGTCIDCHKGIRAPICLDMSSGLQEALRGICRPKPGSCGRRRATRSIRCRRVRALSGR

$R$. sphr DOrC (178-237) NEGGTCIDCHKGIAHKLPDMASGYRALFSKLEKASQSLKPSKGETLYPLQTIEAYLERPS

$E$. coli TorC (165-220) KDNQSCIDCHKGIAHQLPDMSSGFR--KQFDDVRASANDSG - DTLYSIDIKPIYAAKGD

P. stut NirT (174-201) EDNLTCIACHKGIAHHLPEGMTEED--ED

R. sphr NapC (172-227) TEGYTCIDCHKGIAHELPDMRGIDPGWLPPADLRASLPDHG---SSFDLEGARAYVAD--

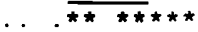

R. caps DorC (220-277) -TERRREGG-GQGDRGDADGGRGGLGQCAAGQAGRLAAGRRRADALCRAGRRIFNVALAP

$R$. sphr DorC (295-351) GDKAKGDGRLLAATPMQVVDVKGEWVQVAVKGWQQEGAER - - VIYEKQGKRI FNAALAP

E. coli TorC (293-349) ---KEASGSLLPASEVKVLKRDGDWLQIEITGWTESAGRQR--VLTQFPGKRIFVASIRG

* $\quad$ ****

$R$. caps DorC (278-337) TAVAAVVPGTRIDRSRQPDTDQVWTDGTLTVWVKNADLTDSLDKVWSYAGSMFSAACGTC

R. sphr DorC (295-351) TATGSIVAGASMVD---PDTEQTWTDVSLTAWVRNRDLTDDQEALWQYGKQMFNGACGMC

E. COIi TOrC (293-349) DVQQQVKTLEKTTVA---DTNTEWSKLQATAWMKKGDMVNDIKPIWAYADSLYNGTCNQC

R. caps DorC (338-388) HVLPHTSHFLANHWIGTLNAMKPKAPLNEEQFRLVQKYVQMHAKDMGGESR--.--

$R$. sphr DOrC (352-404) HVLPHTEHFLANQWIGTLNAMKSRAPLDDEQFRLVQRYVQMHAKDVEPEGAAE-....

E. COIi TOrC (350-390) HGAPEIAHFDANGWIGTLNGMIGFTSLDKREERTLLKYLQMNASDTAGKAHGDKKEEK

$\star \star \star \star \star \star \star \star \star \star \star \star \star \star \star * * * * * *$

Fig. 2. Sequence alignment of $R$. capsulatus DorC, $R$. sphaeroides DorC (Mouncey et al., 1997), E. coli TorC (Mejean et al., 1994), Pseudomonas stutzeri NirT (Jungst et al., 1991) and R. sphaeroides NapC (Reyes et al., 1996). Consensus c-typehaem-binding motifs are underlined. Asterisks denote amino acids that are identical in all sequences and dots denote conservative changes. The hydrophobic putative membrane anchor at the $\mathrm{N}$ terminus of $R$. capsulatus DorC is shown in bold italics.

TorC are similar to those of the tetrahaem members of the NirT family. However, DorC and TorC have a Cterminal extension of about 180 aa compared to the tetrahaem cytochromes. This contains the fifth $c$-typehaem-binding motif and so DorC and TorC form a subclass of pentahaem cytochromes within the NirT family. The sequence alignment between DorC, TorC and the tetrahaem members of the NirT family suggests that the tetrahaem unit must form a functional domain within the pentahaem proteins. This is distinct from the additional haem that is located towards the $\mathrm{C}$ terminus of the pentahaem proteins.

The putative DorD protein has a mass of $21590 \mathrm{Da}$ and a calculated $\mathrm{pI}$ of $8 \cdot 21$. Hydropathy plots indicate that the protein is hydrophobic at the $\mathrm{N}$ and $\mathrm{C}$ termini with a central hydrophilic portion. None of the hydrophobic regions is of sufficient length to form a membranespanning helix and there was no indication of a signal sequence in this protein as predicted by the Von Heijne method. DorD of $R$. capsulatus has highest amino acid sequence similarity to TorD of E. coli $(36 \cdot 10 \%$ similarity and $23.41 \%$ identity) and DorB of $R$. sphaeroides. Another protein from E. coli, ORF Ycac, is also similar to DorD and, interestingly, this protein is located adjacent to the $d m s$ operon in this bacterium. No conserved histidine residues were identified in the TorD/DorD family of proteins; this is taken to indicate that these proteins are highly unlikely to encode a haembinding protein.

The putative DorB protein has a calculated molecular mass of $11987 \mathrm{Da}$ and a $\mathrm{pI}$ of $12 \cdot 6$. There is no indication that this protein possesses an $\mathrm{N}$-terminal signal sequence or any membrane-spanning helices. Therefore, it seems likely that DorB is a water-soluble cytoplasmic protein. The only similar protein identified in the databases is NapD from Paracoccus denitrificans (Berks et al., 


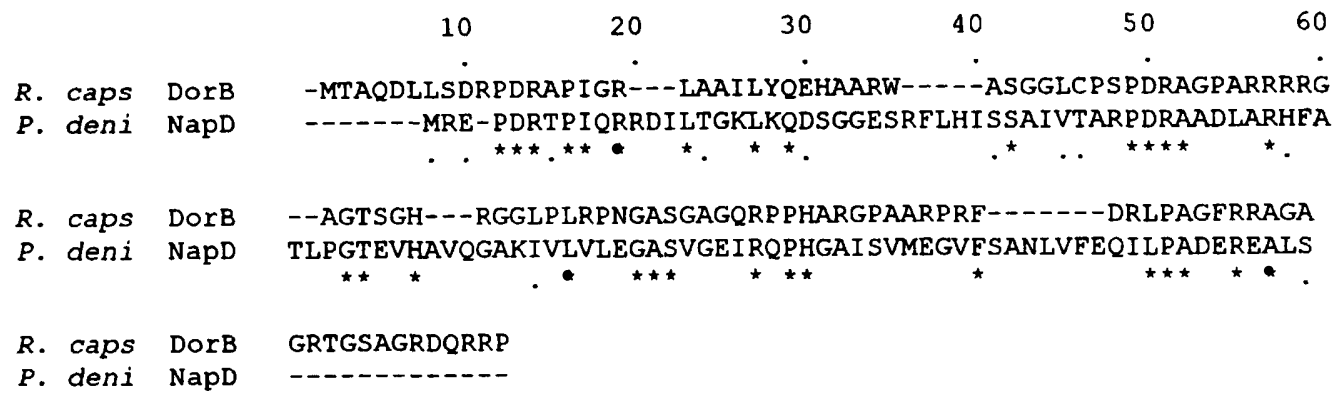

Fig. 3. Sequence alignment of $R$. capsulatus DorB and Paracoccus denitrificans NapD (Berks et al., 1995b). Asterisks denote amino acids that are identical in all sequences and dots denote conservative changes.

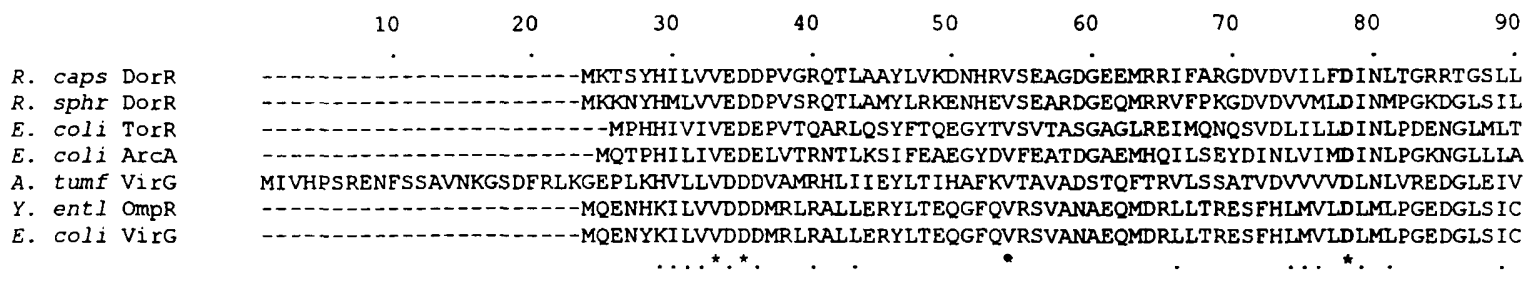

R. caps DorR

R. sphr DorR

E. COli TOrR

E. $\operatorname{coli}$ ArcA

A. tumf VirG

$Y$. entl OmpR

E. Coli VirG

R. Caps DorR

R. sphr DorR

E. Coli TorR

E. Coli ArCA

A. tumf VirG

$Y$. entl OmpR

E. coli VirG
RELRRQSE-VGVIMVTS-RREDVDRIVALELGADDYVTKPYNMREI LPRT RNLARRVTAARVVKADE-- -SRKSFEGWTLDIAHWTLSDP RELPRQSE-VGI IMVTS-RKEDVDRIVALEFGADDYVTKPYNMREI LPRAKNFARRVAALRLVRPDQ---PATTFDGWTLDAAHWALTDP RALRERST-VGI I LVTG-RSDRIDRIVGLEMGADDYVTKPLELRELVVRVKNLLWR IDLAROAOPHT-ODNCYRFAGYCLNVSRHTLERRELREQAN-VALMFLTG-RDNEVDKI LGLE I GADDY ITKP FN PRELT I RARNLLSRTMNLGTVSEERRSVES YKFNGWELDINSRSLI GP RNLAAKSD-I I I I I SGDRLEETDKVVALELGAS DF IAKP FS IREF LARI RVALRVRPNVVRSKDRR - - - SFCFT DWTLNLRQRRLMSE RRLRSQSNPMP I IMVTA-KGEEVDRIVGLE I GADDYI P KPFNPRELLARI RAVLRRQANELPGAPSQ-EETVIAFGKFKLNLGTREMFRRRLRSQSNPMPI IMVTA-KGEEVDRIVGLEIGADDY I PKP FNPRELLARI RAVLRRQANELPGAPSQ-EEAVIAFGKFKLNLGTREMFRE

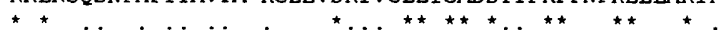

AGEAVKMTRAEFELLATFVTHPGQVLSRDQLMTHVQPAAGMKAY DTHHIDVLVRRVRRKIEPDTGQAPADVHRARVGYVFSA----- -AGNHVKLTRAEEELLATFVAHPGQVLT RDQLMNHVG-RRGHETF DR-TIDVLVRRIRRKIEADP SDPRLIVTVHGI GYVFQA-- - - -

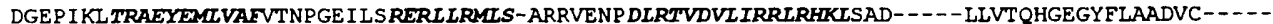
DGEQYKLPRSEFRAMLHFCENPGKIQSRAELIKROIT-GRELKPHDR-TVDVTIRRIRKTHESTPDT PE I IAT I HGEGYRFCGDLED--- AGGEVKL TAGEFNLLLAFLEKP RDVL SREQLLIASR-VRDEEVYDR-SIDVLILRLRRKLEADP SS PQLI KTARGAGYFFDADVQVSHGG EDEPMPITSGEEAVLKALVSHPREPLSRDKLMNLAR-GREYSAMER-SIDVOISRLRRMVEEDPAHPRYIOTVWGLGYVFVPDGSKA--DE PMP-L TSGEFAVLKALVSHPRE PLS RDKLMNLAR-GREYSAMER-SIDVQISRLRRMVEEDPAHPRYIQTVWGLGYVFVPDGSKA---

Fig. 4. Sequence alignment of DorR with related bacterial response regulators. Asterisks denote amino acids that are identical in all sequences and dots denote conservative changes. The three helices of the DNA-binding helix-turn-helix of OmpR and E. coli VirG are known (Suzuki \& Brenner, 1995) and are highlighted in bold italics and underlined. The corresponding regions of the other proteins would be expected to form functional helix-turn-helix DNA-binding domains and have been highlighted in bold italics only. A. tumf, Agrobacterium tumefaciens; $Y$. entl, Yersinia enterocolitica.

1995a). DorB has $37 \cdot 5 \%$ similarity and $27 \cdot 7 \%$ identity to NapD (Fig. 3).

Fig. 4. shows an alignment of DorR with response regulators of the OmpR subclass. This includes DorR from $R$. sphaeroides and TorR from E. coli, response regulators involved in the induction of DMSO respiration and TMAO respiration, respectively. By analogy with TorR it is expected that in R. capsulatus DorR the phosphoryl acceptor in the $\mathrm{N}$-terminal receiver domain is Asp-55. Part of an ORF was identified $5^{\prime}$ of dorR which appears to be transcribed in the opposite direction to dorR. The derived amino acid sequence of part of this gene indicates that it encodes a sensor histidine kinase. This ORF has highest sequence similarity to E. coli TorS and R. sphaeroides DorS (data not shown). These are complex sensors which possess both classical and alternative transmitter domains, separated by a receiver domain which is homologous to the domain found in response regulators (Parkinson, 1993). Although the sequence information for $R$. capsulatus DorS is incomplete it also appears to be a complex sensor; the aspartyl residue of the receiver domain which acts as a phosphoryl receiver is conserved while a conserved histidine is present in the alternative transmitter domain.

\section{A dorC mutation abolishes expression of a $46 \mathrm{kDa}$ DMSO-inducible cytochrome}

$\operatorname{dor} C$ of $R$. capsulatus was inactivated in vitro by insertion of a $\mathrm{Gm}$ resistance cassette. This mutated dorC was exchanged for the wild-type copy of $d o r C$ by sitespecific recombination, as described in Methods. Two mutants were constructed in which the Gm cassette is transcribed in a direction opposite to that of the dor operon (mutant dorC1) and in which transcription of 


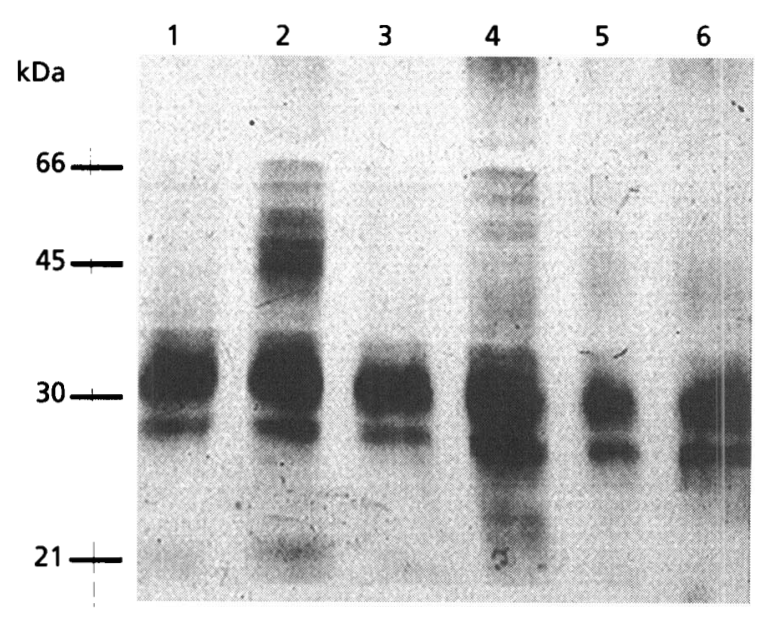

Fig. 5. Analysis of polypeptides from membranes of $R$. capsulatus for haem-dependent peroxidase activity. Polypeptides were separated using SDS-PAGE, $50 \mu \mathrm{g}$ protein per lane. Lanes: 1, strain 37b4 (wild-type) grown in absence of DMSO; 2, strain 37b4 grown in presence of DMSO; 3 and 4, dorC2 grown in the absence and presence of DMSO, respectively; 5 and 6 , dor $\mathrm{C} 1$ grown in the absence and presence of DMSO, respectively.

the $\mathrm{Gm}$ cassette is in the same direction as $\operatorname{dor} \mathrm{C}$ (mutant dorC2). The presence of a DMSO-inducible $c$-type cytochrome in membranes of $R$. capsulatus and $R$. sphaeroides has been recognized for many years and it can be observed as a polypeptide that stains for haemdependent peroxidase activity. Fig. 5 shows a SDSPAGE gel of cell extracts from wild-type $R$. capsulatus and the $d_{0} \mathrm{C}$ mutants stained for haem-dependent peroxidase activity. In extracts from wild-type cells a DMSO-inducible haem-staining polypeptide was observed with a molecular mass of about $46 \mathrm{kDa}$ (Fig. 5, lane 2). This haem-staining polypeptide was absent from mutants dorC1 and dorC2 (Fig. 5, lanes 4 and 6). The above data show that the $46 \mathrm{kDa}$ cytochrome is the dorC gene product. It was also observed that, unlike wild-type cells, neither $\operatorname{dor} \mathrm{C} 1$ nor $\operatorname{dor} \mathrm{C} 2$ was able to grow anaerobically in the dark with DMSO as electron acceptor (data not shown) and this provides further evidence that DorC is essential for DMSO respiration.

\section{Expression of DMSO reductase in dorA, dorC, dorD and dorB mutants}

A $\operatorname{dor} A$ mutant was constructed as described in Methods. This mutant exhibited no DMSO reductase activity with reduced methylviologen and no DMSO reductase polypeptide could be detected using an antiDMSO reductase antibody in cell-free extracts of the mutant (data not shown). The sequence and mutational analysis of the dor genes predicts that DorC and DorA are electron transport proteins. This raised the question of the role of DorD and DorB, as well as the question of whether the dor genes form an operon. To address these questions, the effects of mutations in three dor genes on the expression of DMSO reductase were analysed. Mutant dorC1 showed a loss of reduced methylviologenDMSO oxidoreductase activity (Table 2). A Western blot of cell extracts from dorC1 showed that the DorA polypeptide was not produced in this mutant (Fig. 6a, lane 2). Mutant $\operatorname{dor} \mathrm{C} 2$ showed a decrease in reduced methylviologen-DMSO reductase activity to a level equal to $45 \%$ of wild-type activity (Table 2). A Western blot of cell-free extracts from dorC2 showed that the DorA polypeptide could be detected (Fig. 6a, lane 1). This suggested that a polar mutation in $\operatorname{dor} C$ abolished dorA expression while this continued in cells containing a non-polar mutation in $d o r C$.

Two dorD mutants were constructed as described in the Methods. In dorD1 the Gm cassette is transcribed in a direction opposite to that of the dor operon while in mutant dorD2 transcription of the $\mathrm{Gm}$ cassette proceeds in the same direction as dorD. Mutants dorD1 and dorD2 showed a complete loss of both reduced methylviologen-DMSO oxidoreductase activity (Table 2 ) and polypeptide production, as indicated by Western blotting (data not shown). Chromosomal dor A : lacZ transcriptional fusions were constructed in the $\operatorname{dor} D$ mutants to determine whether dorA was transcribed. As expected

Table 2. DMSO reductase activity and expression of dorA and moaA transcriptional fusions in wild-type $R$. capsulatus $37 \mathrm{~b} 4$ and dor mutants

All cells were grown phototrophically in the presence of DMSO as described in the Methods. One unit of DMSO reductase activity is defined as $1 \mu \mathrm{mol}$ methylviologen oxidized $\min ^{-1}(\mathrm{mg} \text { protein })^{-1}$. ND, Not detected.

\begin{tabular}{|lccc|}
\hline Sample & $\begin{array}{c}\text { DMSO reductase } \\
\text { activity (units) }\end{array}$ & $\begin{array}{c}\phi[\text { dor } A:: \text { lac Z }] \text { activity } \\
\text { (Miller units) }\end{array}$ & $\begin{array}{c}\phi[\text { moa } A:: \text { lacZ }] \text { activity } \\
\text { (Miller units) }\end{array}$ \\
\hline $37 \mathrm{~b} 4$ & $28 \cdot 0$ & $29 \cdot 3( \pm 3 \cdot 9)$ & $69 \cdot 8( \pm 1 \cdot 3)$ \\
$\operatorname{dor} C 1$ & 0 & ND & ND \\
$\operatorname{dor} C 2$ & $12 \cdot 6$ & ND & ND \\
$\operatorname{dor} D 1$ & 0 & 0 & ND \\
$\operatorname{dor} D 2$ & 0 & $13 \cdot 7( \pm 0 \cdot 5)$ & ND \\
$\operatorname{dor} B 1$ & $5 \cdot 0$ & ND & 0 \\
$\operatorname{dor} B 2$ & $11 \cdot 5$ & ND & $22 \cdot 3( \pm 1 \cdot 7)$ \\
\hline
\end{tabular}


(a)

1

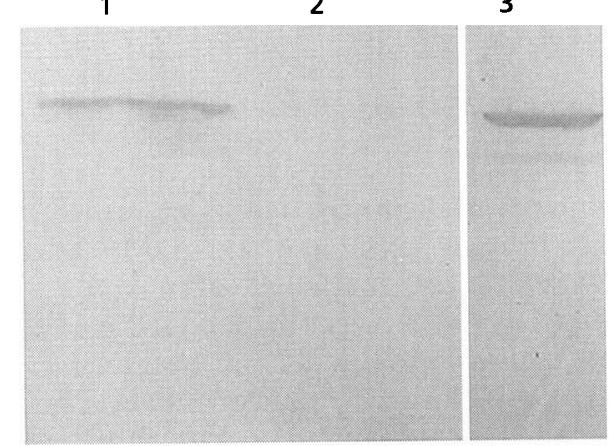

(b)

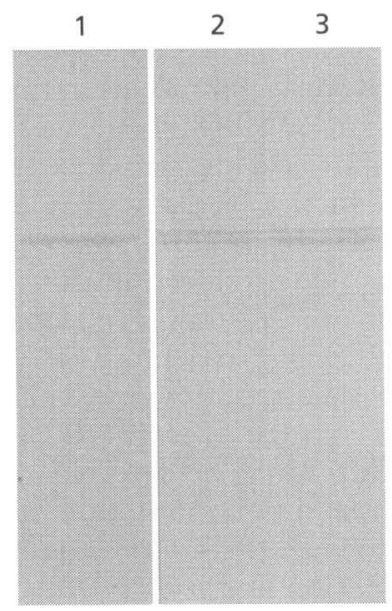

Fig. 6. (a) Western blot of cell extracts of dorC mutants probed with anti-DorA antibody. Each lane contains $20 \mu \mathrm{g}$ protein from cells grown in the presence of DMSO. Lanes: 1, dorC2; 2, dorC1; 3, 37b4. (b) Western blot of cell extracts of dorB mutants probed with anti-DorA antibody. Each lane contains $20 \mu \mathrm{g}$ protein from cells grown in the presence of DMSO. Lanes: 1 , $37 \mathrm{~b} 4 ; 2$, dorB1; 3, dorB2.

$\phi[\operatorname{dor} A::$ lacZ $]$ activity in $\operatorname{dorD} 1$ was zero but in $\operatorname{dorD} 2$ the activity was slightly under $50 \%$ of the activity in wild-type cells (Table 2). Thus, the failure to detect
DMSO reductase polypeptide in dorD2 was not due to the abolition of the transcription of $\operatorname{dor} A$.

Two dor $B$ mutants were constructed as described in Methods. Table 2 shows that polar and non-polar mutations in $\operatorname{dor} B$ reduced, but did not abolish, the activity of DMSO reductase. DMSO reductase activity in mutants dorB1 and dorB2 was 18 and $41 \%$ of that in wild-type cells, respectively. Western blots of crude extracts of both mutants showed that two polypeptides reacted with anti-DMSO reductase (Fig. 6 b, lanes 2 and $3)$. The smaller polypeptide had a molecular mass of $85 \mathrm{kDa}$, identical to that of purified DMSO reductase. The larger polypeptide was not observed in cell-free extracts from wild-type cells and had a mass about $5 \mathrm{kDa}$ greater than the smaller polypeptide. The organization of the dor gene cluster (Fig. 1) leads to the possibility that a polar mutation in $\operatorname{dor} B$ might abolish the expression of the Moco biosynthetic genes. Hence, the expression of a moaA: lac $Z$ transcriptional fusion was measured in mutants $\operatorname{dor} B 1$ and $\operatorname{dor} B 2$. The results showed that the $\phi[\mathrm{moaA}:: \mathrm{lac} Z]$ activity was 0 and $22 \cdot 3$ Miller units in $\operatorname{dor} 1$ and $d o r B 2$, respectively, compared to 70 Miller units in wild-type cells.

\section{Regulation of the expression of the dorCDA operon by Fnr and the presence of an electron acceptor}

Some of the physiological factors regulating the expression of DMSO reductase in $R$. capsulatus have already been identified but the details of the regulation of transcription have not been established. To address this question chromosomal $\operatorname{dor} A:$ :lacZYA transcriptional fusions were constructed in wild-type $R$. capsulatus and a number of mutants and $\phi[\operatorname{dor} A:: \operatorname{lac} Z]$ activity was measured in cells grown aerobically and anaerobically as described in Methods section. Expression of the $\operatorname{dor} C D A$ operon was not detectable in cells grown at high oxygen tension but a low level of expression could be observed when the cells were grown at low oxygen tension (data not shown). The presence of DMSO in anaerobic cultures led to a greater than $40-$ fold increase in $\phi[\operatorname{dor} A::$ lac $Z]$ activity while addition of TMAO led to only about a 7-fold increase (Table 3 ).

Table 3. $\phi[$ dorA: : lacZ] expression in $R$. capsulatus strains grown under phototrophic (anaerobic conditions) in the presence and absence of DMSO and TMAO

\begin{tabular}{|c|c|}
\hline Sample & $\beta$-Galactosidase activity (Miller units) \\
\hline 37b4 (wild-type) & ND \\
\hline $37 \mathrm{~b} 4 \phi[\operatorname{dor} A:: \operatorname{lac} Z]$ & $1 \cdot 6 \pm 0 \cdot 3$ \\
\hline $37 \mathrm{~b} 4 \phi[\operatorname{dor} A:: \operatorname{lac} Z]+\mathrm{DMSO}$ & $71 \cdot 8 \pm 2 \cdot 2$ \\
\hline $37 \mathrm{~b} 4 \phi[\operatorname{dor} A:: \operatorname{lac} Z]+\mathrm{TMAO}$ & $11 \cdot 4 \pm 1 \cdot 6$ \\
\hline RGK295 $(\Delta f n r) \phi[$ dor $A::$ lacZ $]$ & $8 \cdot 3 \pm 0 \cdot 5$ \\
\hline RGK295 $(\Delta f n r) \phi[$ dor $A:: l a c Z]+$ DMSO & $3 \cdot 5 \pm 0 \cdot 8$ \\
\hline RGK295 $(\Delta f n r) \phi[$ dor $A:: l a c Z]+$ TMAO & $2 \cdot 6 \pm 0 \cdot 9$ \\
\hline $37 \mathrm{~b} 4 \Delta d \operatorname{dor} R \phi[\operatorname{dor} A:: \operatorname{lac} Z]$ & ND \\
\hline $37 \mathrm{~b} 4 \Delta \operatorname{dorR} \phi[\operatorname{dor} A::$ lacZ $]+\mathrm{DMSO}$ & ND \\
\hline
\end{tabular}

ND, Not detected. 
It has been reported that Fnr is essential for the synthesis of DMSO reductase in $R$. capsulatus (Zeilstra-Ryalls et al., 1997), although no study of transcriptional regulation was made. Table 3 shows that in an FNR mutant of $R$. capsulatus a basal level of $\phi[$ dor $A:$ : lacZ $]$ activity was detected in microaerobic cells. However, the addition of DMSO or TMAO failed to induce expression of the dorCDA operon, in contrast to the situation in wild-type cells. In view of the observations made in $R$. sphaeroides (Mouncey \& Kaplan, 1998) and E. coli (Jourlin et al., 1996a, b), it seems likely that the DorS/DorR two-component system is responsible for the induction of $\operatorname{dor} C D A$ operon expression by DMSO and TMAO. This was confirmed by constructing a $d o r R$ mutant and in this case no $\phi[\operatorname{dor} A:$ : lac $Z]$ activity could be detected under any growth conditions (Table 3 ).

\section{DISCUSSION}

Although many facultative aerobic bacteria are able to use DMSO and TMAO as electron acceptors in anaerobic respiration, it is only in E. coli that the operons encoding the components of these respiratory pathways have been investigated in detail (Mejean et al., 1994). The tor operon encoding the TMAO respiratory proteins was shown to contain two genes, tor $C$ and tor $D$, in addition to the TMAO reductase structural gene, torA (Mejean et al., 1994). The results described in this paper have shown that genes homologous to tor $C$ and tor $D$ are linked to $\operatorname{dor} A$ of $R$. capsulatus. A second oxidoreductase in $E$. coli uses DMSO as the preferred substrate and can be purified as a menaquinol-DMSO oxidoreductase (Weiner et al., 1988). This DMSO reductase is encoded by the $d m s A B C$ operon (Weiner et al., 1992). The sequence analysis of $\operatorname{dor} C D A$ from $R$. capsulatus confirms that it should be compared with torCAD and not $d m s A B C$ from $E$. coli. The experiments with the $\operatorname{dor} C$ and $\operatorname{dorD}$ mutants in which the $\mathrm{Gm}$ cassette was inserted so that there is a polar effect on transcription resulted in no DMSO reductase polypeptide being produced. This observation is consistent with the view that there is no promoter for $\operatorname{dor} A$ expression within $\operatorname{dor} C$ or $d o r D$ and that $\operatorname{dor} C D A$ forms an operon. The presence of a likely transcription terminator immediately after the translation stop codon of $\operatorname{dor} A$ suggests that these three cistrons are co-transcribed. However, the presence of an additional ORF (dorB) and a Moco biosynthetic gene cluster which is essential for DMSO reductase activity (Solomon et al., 1999) suggests that transcription of the dor gene cluster may be complex. One possibility is that $\operatorname{dor} C D A$ transcripts plus larger transcripts might be generated by read-through beyond the putative transcription terminator. This possibility is currently under investigation.

The electron transfer components connecting the ubiquinol pool to DMSO reductase have been identified as cytochromes using spectroscopic methods (McEwan et al., 1989). DorC has five C-X-X-C-H motifs, indicating that this protein represents the $c$-type cytochromes which can be detected in reduced-minus-DMSO oxidized difference spectra in $R$. capsulatus (McEwan et al.,
1989). A similar protein, TorC, is present in E. coli (Mejean et al., 1994). The broad $\alpha$ absorption band of the cytochrome in reduced-minus-DMSO oxidized spectra of whole cells of $R$. capsulatus is consistent with the oxidation of a cytochrome with several haem centres with absorption maxima ranging from 550 to almost $560 \mathrm{~nm}$ (McEwan et al., 1989). Indeed, since DorD is highly unlikely to be a haemoprotein, it is probable that DorC is responsible for all of the absorption changes observed in the difference spectra and that no $b$-type cytochrome, in addition to $c$-type cytochrome(s), is involved in this pathway, in contrast to the suggestion of McEwan et al. (1989).

In $E$. coli the presence of $\operatorname{tor} C$ has also been correlated with the production of a haem-staining polypeptide of apparent molecular mass $46 \mathrm{kDa}$ and this is almost certainly TorC (Ujiiye et al., 1996). In R. capsulatus the situation is more complicated because of the presence of a DMSO-induced $44 \mathrm{kDa}$ cytochrome (Hanlon et al., 1992) which is almost certainly a cytochrome $c$ peroxidase (CCP). However, CCP is mainly located in the periplasm of $R$. capsulatus, in contrast to DorC that is a membrane-bound protein (A. L. Shaw \& A. G. McEwan, unpublished observations). The data shown in Fig. 5 are consistent with the view that the membranebound $44 \mathrm{kDa}$ cytochrome induced by DMSO is the dor $C$ gene product. A similar conclusion has been made by Mouncey et al. (1997) in R. sphaeroides.

It seems probable that DorC is bound to the periplasmic face of the cytoplasmic membrane via its hydrophobic $\mathrm{N}$-terminal sequence. Although we identified a potential $\mathrm{N}$-terminal signal polypeptide in DorC, it is possible that it is not cleaved; this is the case in another membrane-bound protein which faces the periplasm, cytochrome $c_{\mathrm{y}}$ of $R$. capsulatus (Myllikallio et al., 1997). Sequence analysis showed that DorC, like TorC, is a member of the NirT class of cytochromes. However, these two proteins differ from the other members of the NirT class in that they possess an additional C-terminal domain containing a haem $c$ binding motif. It seems likely that these proteins possess a tetrahaem domain that receives electrons from ubiquinol, as suggested for other members of this class. Electrons would then be transferred to $c$-type cytochrome at the $\mathrm{C}$ terminus and it is this component which may donate electrons to DMSO reductase. In other systems, such as Nap, a distinct periplasmic cytochrome is involved in electron transfer from the NirT class cytochrome to the terminal reductase (Berks et al., 1995a).

Sequence alignment of DorD with TorD of E. coli and Haemophilus influenzae highlights their similarities but offers little clue to their function. DorD is the homologue of DorB from $R$. sphaeroides (Ujiiye et al., 1996; Mouncey et al., 1997) and, in view of the relationship between these proteins and those in enteric bacteria, it is suggested that DorD is a more appropriate name. Although DorD exhibits hydrophobic regions near the $\mathrm{N}$ and $\mathrm{C}$ termini, we have observed that an $\mathrm{N}$-terminal histidine-tagged DorD is water-soluble, suggesting a cytoplasmic location for this protein (A. L. Shaw \& A. 
G. McEwan, unpublished observations). Until recently, the function of the TorD/DorD class of proteins has eluded definition. However, it has now been shown that E. coli TorD acts as a cytoplasmic chaperone-like protein and interacts with unfolded TorA (Pommier et al., 1998). Our results are consistent with a similar role for DorD in the biogenesis of DMSO reductase in $R$. capsulatus. The comparison of mutants dor $\mathrm{C} 2$ and dorD2 showed that DorD was required to allow production of active DMSO reductase. Since dorA was transcribed in the dorD2 mutant, it seems likely that DorA is not stabilized in the absence of DorD and that it is rapidly degraded. However, pulse-chase experiments would be required to verify this view. In earlier work it has been shown that a torD mutation results in lowered amounts of TMAO reductase (Mejean et al., 1994) but the effect was not as dramatic as that of a dorD mutation on the level of DMSO reductase in $R$. capsulatus. One explanation for this could be the presence of a second TorD-like protein, ORF Ycac, which is located close to the dms operon in E. coli (Blattner et al., 1997). Perhaps ORF Ycac has a role in the biogenesis of DMSO reductase and TMAO reductase in E. coli.

The phenotype of the dor $B$ mutant suggests that it is also involved in the biogenesis of DMSO reductase. Both polar and non-polar mutations in $\operatorname{dor} B$ appeared to cause a decrease in the level of moaA expression and as a result the phenotype of the $\operatorname{dor} B$ mutant resembled that of a moaA mutant (Solomon et al., 1999). In these mutants two forms of DMSO reductase polypeptide were observed. We have shown that the small form of DMSO reductase is probably periplasmic mature DMSO reductase while the larger polypeptide is probably cytoplasmic apo-DMSO reductase (Solomon $e t$ al., 1999). A polar mutation in moaA caused a $97 \%$ decrease in DMSO reductase activity but did not affect the activity of other molybdoenzymes (Solomon et al., 1999). In contrast, a polar mutation in dorB caused an $82 \%$ decrease in DMSO reductase activity while a nonpolar mutation in $\operatorname{dor} B$ caused a $42 \%$ decrease. This distinguishes the phenotype of the $\operatorname{dor} B$ mutant from the moaA mutant. Although our experiments do not identify the function of Dor $B$, it is suggested that it has a role in Moco insertion into DorA. If this were the case then DorB may have a role in Moco insertion that is similar to that proposed for $\mathrm{NarJ}$ in the assembly of nitrate reductase (Blasco et al., 1998).

A major difference between the dor and tor systems is their regulation by oxygen. In $E$. coli there is no evidence that Fnr controls the expression of the tor operon and the reason why the tor operon is not expressed under aerobic conditions is not clear. The periplasmic TorT protein could have a role (Jourlin et al., 1996a, b) and it is interesting that the homologue of tor $T$ is absent from the dor gene cluster in R. sphaeroides and $R$. capsulatus. The results in this paper confirm that expression of DMSO reductase in $R$. capsulatus is dependent on Fnr and establish that it affects the transcription of $\operatorname{dor} C D A$. However, it seems unlikely Fnr acts directly to induce expression of this operon; no consensus binding-site for Fnr was identified in the $\operatorname{dor} C D A$ regulatory sequence, even though recognizable Fnr consensus sequences are readily identifiable in $R$. capsulatus (Zeilstra-Ryalls et al., 1997). In R. sphaeroides it appears that Fnr exerts an effect on dor operon expression by positively regulating the expression of the sensor dorS (Mouncey \& Kaplan, 1998). This also seems to be the case in $R$. capsulatus (A. L. Shaw \& A. G. McEwan, unpublished observations) but further analysis is required to determine whether the organization of the dor regulatory region $5^{\prime}$ of $d o r R$ in $R$. capsulatus is the same as that described by Mouncey \& Kaplan (1998) in R. sphaeroides.

\section{ACKNOWLEDGEMENTS}

This work is supported by grant A29531856 to A.G.M. and G.R.H. from the Australian Research Council. A. L.S. is the recipient of an Australian Postgraduate Award. We thank Robert Kranz for supplying the Fnr mutant used in this work.

\section{REFERENCES}

Bennett, B., Benson, N., McEwan, A. G. \& Bray, R. C. (1994). Multiple states of the molybdenum centre of dimethylsulphoxide reductase from $R$ bodobacter capsulatus revealed by EPR spectroscopy. Eur J Biochem 225, 321-331.

Berks, B. C., Ferguson, S. J., Moir, J.W. B. \& Richardson, D. J. (1995a). Enzymes and associated electron transport systems that catalyse the respiratory reduction of nitrogen oxides and oxyanions. Biochim Biophys Acta 1232, 97-173.

Berks, B. C., Richardson, D. J., Reilly, A., Willis, A. C. \& Ferguson, S. J. (1995b). The napEDABC gene cluster encoding the periplasmic nitrate reductase system of Thiosphaera pantotropha. Biochem J 309, 983-992.

Blasco, F., Dos-Santos, J.-P., Magalon, A., Frixon, C., Guigliarelli, B., Santini, C.-L. \& Giordano, G. (1998). NarJ is a specific chaperone required for molybdenum cofactor assembly in nitrate reductase A from E. coli. Mol Microbiol 28, 435-447.

Blattner, F. R., Plunkett, G., Bloch, C. A. \& 14 other authors (1997). The complete genome sequence of Escherichia coli K-12. Science 277, 1453-1474.

Hanlon, S. P., Holt, R. A. \& McEwan, A. G. (1992). The 44-kDa ctype cytochrome induced in Rhodobacter capsulatus during growth with dimethylsulphoxide as an electron acceptor is a cytochrome $c$ peroxidase. FEMS Microbiol Lett 97, 283-288.

Hatton, A. D., Malin, G. R. \& McEwan, A. G. (1994). Identification of a periplasmic dimethylsulphoxide reductase in Hyphomicrobium EG grown under chemolithoheterotrophic conditions with dimethylsulphoxide as carbon source. Arch Microbiol 162, 148-150.

Hirsch, P. R. \& Beringer, J. E. (1984). A physical map of pPH।JI and pJB4JI. Plasmid 12, 139-141.

Jourlin, C., Simon, G., Pommier, J., Chippaux, M. \& Mejean, v. (1996a). The periplasmic TorT protein is required for trimethylamine- $\mathrm{N}$-oxide reductase gene induction in Escherichia coli. J Bacteriol 178, 1219-1223.

Jourlin, C., Bengrine, A., Chippaux, M. \& Mejean, V. (1996b). An unorthodox sensor protein (TorS) mediates the induction of the tor structural genes in response to trimethylamine- $\mathrm{N}$-oxide reductase in in Escherichia coli. Mol Microbiol 20, 1297-1306.

Jungst, A., Wakabayashi, S., Matsubara, H. \& Zumft, W. G. (1991). The nirSTBM region coding for cytochrome $c d_{1}$-dependent nitrite 
respiration of Pseudomonas stutzeri consists of a cluster of mono-, di- and tetra-heme proteins. FEBS Lett 279, 205-209.

Kaufmann, N., Hudig, H. \& Drews, G. (1984). Transposon Tn5 mutagenesis of genes for the photosynthetic apparatus in $R$ hodopseudomonas capsulata. Mol Gen Genet 198, 153-158.

Kelly, D. J., Richardson, D. J., Ferguson, S. J. \& Jackson, J. B. (1988). Isolation of transposon $\operatorname{Tn} 5$ insertion mutants of Rhodobacter capsulatus unable to reduce trimethylamine- $N$ oxide and DMSO. Arch Microbiol 150, 138-144.

Kisker, C., Schindelin, H. \& Rees, D. C. (1997). Molybdenum cofactor-containing enzymes: structure and mechanism. Annu Rev Bioihem 66, 233-267.

Knaeblein, J., Mann, K., Ehlert, S., Fonstein, M., Huber, R. \& Schneider, F. (1996). Isolation, cloning, sequence, analysis and localisation of the operon encoding dimethyl sulfoxide/ trimethylamine $N$-oxide reductase from $R$ hodobacter capsulatus. J Mol Biol 263, 40-52.

Labes, M., Puhler, A. \& Simon, R. (1990). A new family of RSF1010-derived expression and lac-fusion broad-host-range vectors for gram-negative bacteria. Gene 89, 37-46.

McAlpine, A. S., McEwan, A. G., Shaw, A. L. \& Bailey, S. (1997). Molybdenum active centre of DMSO reductase from Rhodobacter capsulatus: crystal structure of the oxidised enzyme at $1.82 \AA$ resolution and the dithionite-reduced enzyme at $2.8 \AA$ resolution. J Biol Inorg Chem 2, 690-701.

McEwan, A. G., Wetzstein, H. G., Ferguson, S. J. \& Jackson, J. B. (1985). Periplasmic location of the terminal oxidoreductase in trimethylamine- $\mathrm{N}$-oxide and dimethylsulphoxide respiration in the photosynthetic bacterium Rhodopseudomonas capsulata. Biochim Biophys Acta 806, 140-147.

McEwan, A. G., Richardson, D. J., Hudig, H., Ferguson, S. J. \& Jackson, J. B. (1989). Identification of cytochromes involved in electron transport to trimethylamine $N$-oxide/DMSO reductase in Rhodobacter capsulatus. Biochim Biophys Acta 973, 308-314.

MasepohI, B., Klipp, W. \& Puhler, A. (1988). Genetic characterisation and sequence analysis of the duplicated nif $A /$ nif $B$ gene region of Rhodobacter capsulatus. Mol Gen Genet 212, 27-37.

Mejean, V., lobbi Nivol, C., Lepelletier, M. \& 7 other authors (1994). TMAO anaerobic respiration in Escherichia coli: Involvement of the tor operon. Mol Microbiol 11, 1169-1179.

Miller, J. H. (1972). Experiments in Molecular Genetics. Cold Spring Harbor, NY: Cold Spring Harbor Laboratory.

Mouncey, N. \& Kaplan, S. (1998). Redox-dependent gene regulation in Rhodobacter sphaeroides $2.4 .1^{\mathrm{T}}$ : effects on dimethylsulfoxide reductase (dor) gene expression. J Bacteriol 180, $5612-5618$

Mouncey, N., Choudhary, M. \& Kaplan, S. (1997). Characterisation of the genes encoding dimethylsulfoxide reductase of Rhodobacter sphaeroides 2.4.1 ${ }^{\mathrm{T}}$ : an essential metabolic gene function encoded by chromosome II. J Bacteriol 179, 7617-7624.

Myllikallio, H., Jenney, F. E., Moomaw, C. R., Slaughter, C. A. \& Daldal, F. (1997). Cytochrome $c(y)$ of Rbodobacter capsulatus is attached to the cytoplasmic membrane by an uncleaved signal sequence-like anchor. J Bacteriol 179, 2623-2631.

Parkinson, J. S. (1993). Signal transduction schemes of bacteria. Cell 73, 857-871.

Pommier, J., Mejean, V., Giordano, G. \& lobbi-Nivol, C. (1998). TorD, a cytoplasmic chaperone that interacts with the unfolded trimethylamine- $\mathrm{N}$-oxide reductase enzyme (TorA) in Escherichia coli. J Biol Chem 273, 16615-16620.

Pridmore, R. D. (1987). New and versatile cloning vectors with kanamycin-resistance marker. Gene 56, 309-312.
Reyes, F., Roldan, M. D., Klipp, W., Castillo, F. \& Moreno-Vivian, C. (1996). Isolation of periplasmic nitrate reductase genes from Rhodobacter sphaeroides DSM 158: structural and functional differences among prokarotic nitrate reductases. Mol Microbiol 19, 1307-1318.

Sambrook, J., Fritsch, E. F. \& Maniatis, T. (1989). Molecular Cloning: a Laboratory Manual, 2nd edn. Cold Spring Harbor, NY : Cold Spring Harbor Laboratory.

Satoh, T. \& Kurihara, F. N. (1987). Purification and properties of DMSO reductase containing a molybdenum cofactor from a photodenitrifier, Rhodopseudomonas sphaeroides denitrificans. J Biochem 102, 191-198.

Schindelin, H., Kisker, C., Hilton, J., Rajagopalan, K. V. \& Rees, D. C. (1996). Crystal structure of DMSO reductase: Redox-linked changes in molybdopterin coordination. Science 272, 1615-1620.

Schneider, F., Lowe, J., Huber, R., Schindelin, H., Kisker, C. \& Knablein, J. (1996). Crystal structure of dimethyl sulfoxide reductase from Rhodobacter capsulatus at $1.88 \AA$ resolution. J Mol Biol 263, 53-69.

Shaw, A. L., Hanson, G. R. \& McEwan, A. G. (1996). Cloning and sequence analysis of the dimethylsulfoxide reductase structural gene from Rhodobacter capsulatus. Biochim Biophys Acta 1276, 176-180.

Simon, G., Jourlin, C., Ansaldi, M., Pascal, M., Chippaux, M. \& Mejean, V. (1995). Binding of the TorR regulator to cis-acting direct repeats activates tor operon expression. Mol Microbiol 17, 971-980.

Simon, R., Priefer, U. \& Puhler, A. (1983). A broad host range mobilization system for in vivo genetic engineering: transposon mutagenesis in Gram negative bacteria. Bio/Technology 1, 784-791.

Solomon, P. S., Shaw, A. L., Lane, I., Hanson, G. R., Palmer, T. \& McEwan, A. G. (1999). Characterisation of a molybdenum cofactor biosynthetic gene cluster in Rhodobacter capsulatus which is specific for the biogenesis of dimethylsulfoxide reductase. Microbiology 145, 1421-1429.

Suzuki, M. \& Brenner, S. E. (1995). Classification of multi-helical DNA-binding domains and application to predict the DBD structures of sigma factor, LysR, OmpR/PhoB, CENP-B, Rap1 and XylS?Ada?AraC. FEBS Lett 372, 215-221.

Ujiiye, T., Yamamoto, I., Nakama, H., Okubo, A., Yamazaki, S. \& Satoh, T. (1996). Nucleotide sequence of the genes, encoding the pentaheme cytochrome $(d m s C)$ and the transmembrane protein $(d m s B)$, involved in dimethyl sulfoxide respiration from $R$ hodobacter sphaeroides f. sp. denitrificans. Biochim Biophys Acta $1277,1-5$.

Vargas, C., McEwan, A. G. \& Downie, J. A. (1993). Detection of $c$-type cytochromes using enhanced chemiluminescence. Anal Biochem 209, 323-326.

Vieira, J. \& Messing, J. (1982). The pUC plasmids, an M13mp7derived system for insertion mutagenesis and sequencing with synthetic universal primers. Gene 19, 259-268.

Von Heijne, G. (1986). Net amino-terminal-carboxyl terminal charge imbalance may be important for signal sequence function in bacteria. J Mol Biol 192, 287-290.

Weaver, P. F., Wall, J. D. \& Gest, H. (1975). Characterisation of Rhodopseudomonas capsulata. Arch Microbiol 105, 207-216.

Weiner, J. H., Macisaac, D. P., Bishop, R. E. \& Bilous, P. T. (1988). Purification and properties of Escherichia coli DMSO reductase, an iron-sulfur molybdoenzyme with broad substrate specificity. $J$ Bacteriol 170, 1505-1510.

Weiner, J. H., Rothery, R. A., Sambasivarao, D. \& Treiber, C. A. 
(1992). Molecular analysis of dimethylsulfoxide reductase: a complex iron-sulfur molybdoenzyme of Escherichia coli. Biochim Biophys Acta 1102, 1-18.

Yamamoto, I., Wada, N., Ujiiye, T. \& 8 other authors (1995). Cloning and nucleotide sequence of the gene encoding dimethyl sulfoxide reductase from $R$ hodobacter sphaeroides $\mathrm{f}$. $\mathrm{sp}$. denitrificans. Biosci Biotechnol Biochem 59, 1850-1855.

Yanisch-Perron, C., Vieira, J. \& Messing, J. (1985). Improved M13 phage cloning vectors and host strains: nucleotide sequences of the M13mp18 and pUC19 vectors. Gene 33, 103-119.
Zannoni, D. (1995). Aerobic and anaerobic transport chains in anoxygenic phototrophic bacteria. In Anoxygenic Photosynthetic Bacteria, pp. 949-971. Edited by R. E. Blakenship, M. T. Madigan \& C. E. Bauer. London: Kluwer Academic Publishers.

Zeilstra-Ryalls, J. H., Gabbert, K., Mouncey, N. J., Kaplan, S. \& Kranz, R. G. (1997). Analysis of the $f n r L$ gene and its function in Rhodobacter capsulatus. J Bacteriol 179, 7264-7273.

Received 5 January 1999; revised 1 February 1999; accepted 23 February 1999. 